\title{
Effects of Ametryn on Microbial Activity in Soil with Biofertilizer Addition
}

\author{
Ana Paula Justiniano Régo (Corresponding author) \\ Center of Nuclear Energy in Agriculture, University of São Paulo \\ Avenue: Centenário, n. 303. Piracicaba, SP, 13400-970, Brazil \\ Tel: 55 (19) 3429-4765 E-mail: justiniano@usp.br
}

Kassio Ferreira Mendes

Center of Nuclear Energy in Agriculture, University of São Paulo

Avenue: Centenário, n. 303. Piracicaba, SP, 13400-970, Brazil

Tel: 55 (19) 3429-4765 E-mail: kassio_mendes_06@hotmail.com

Cassiana Maria Reganhan Coneglian

Faculty of Technology, State University of Campinas

Rua Paschoal Marmo, $\mathrm{n}^{\circ}$ 1888, Brazil

Tel: +55-(19) 2113-3347 E-mail: cassianac@ft.unicamp.br

Valdemar Luiz Tornisielo

Center of Nuclear Energy in Agriculture, University of São Paulo

Avenue: Centenário, n. 303. Piracicaba, SP, 13400-970, Brazil

Tel: 55 (19) 3429-4762 E-mail: vltornis@ cena.usp.br

Received: July 31, 2018

doi:10.5296/jas.v6i3.13711
Accepted: August 17, 2018

URL: https://doi.org/10.5296/jas.v6i3.13711 


\begin{abstract}
In recent years, pesticide application has increased worldwide due to the need for increased food production. In this way, understanding of the effects that these xenobiotic molecules can result in the soil microbiota becomes fundamental. Thus, this work aimed to evaluate microbial enzymatic activity by FDA, as well as quantify bacteria and fungi contaminated soil by ametryn herbicide. In addition, biofertilizer was added as a form of microbial biostimulation in order to cause enrichment of the affected site. The ametryn herbicide was chosen because it is widely used in sugarcane crops in Brazil, in the control of weeds, and is moderately persistent in the environment. It can be evaluated that the biofertilizer was fundamental in increasing the microbial activity of the soil, even in the presence of ametryn, probably contributing to its biodegradation. The estimation of the enzymatic activity by FDA, was essential for the evaluation of the increase of the microbial action, contributing to the verification of the active microbiota in the soil. It is suggested the application of biofertilizer in soils contaminated by ametryn, as a way to mitigate affected sites.
\end{abstract}

Keywords: nutrients, herbicide, microrganisms

\title{
1. Introduction
}

Herbicides are the most commonly used groups of pesticides, which can act in contact with the plant or be translocated into the plant, which are more important to combat perennial weeds. Most pesticides applied to crops end up in water and soil, resulting in environmental contamination (Nicolopoulou-Stamati et al., 2016).

Ametryn is a herbicide belonging to the group of s-triazines widely used in sugarcane, corn and pineapple plantations, among others, in pre and post emergence periods for the control of weeds and grasses. It is a herbicide with a strong potential for contamination of surface and groundwater due to its environmental persistence, leaching and surface runoff (PPDB, 2018).

However, pesticides can positively or negatively influence soil microbiota dynamics, which in turn influence soil nutrient behavior (Nicolopoulou-Stamati et al., 2016).

Several studies in the literature such as Jilani et al. (2007), Souza and Resende (2003), Santos (1992) and Bettiol et al. (1998), have applied organic substrates to stimulate the local microbiota to aid in the biodegradation of the xenobiotic compounds discarded in the soil.

Biofertilizers are organic compounds rich in nutrients and contain microbial biomass, capable of nutritionally supplying the soil, aiding in the metabolic activity of the local community. Régo et al. (2014) when evaluating microbial respiration in soil contaminated with ametryn, observed that there was an increase in respiration rate, quantified by the accumulation of $\mathrm{CO} 2$ generation over time.

Thus, this work aims to evaluate the enzymatic activity by the FDA method and the quantification of bacteria and fungi, by the plating method, in soil contaminated by ametryn. As a form of microbial biostimulation, biofertilizer was applied in order to promote the enrichment of the affected soil. 


\section{Mll Macrothink}

\section{Material and Methods}

\subsection{Ametryn Herbicide}

For the purpose of this study, the herbicide ametryn of the brand Fluka (Germany), with $98.5 \%$ purity, in the granular form was used.

\subsection{Biofertilizer}

The Microge ${ }^{\mathrm{o} \circledast}$ biofertilizer was provided by the company Microbiol Biotecnologia, in the municipality of Limeira-SP, which was patented by the same, with registration PI0207342-0 A2.

It was formed by fermented organic compounds containing living or latent cells of microorganisms (bacteria, yeasts, algae and filamentous fungi) and by their metabolites, in addition to organo-mineral chelates. Its production is based on composting (fermentation) in liquid medium, continuously and carried out in the same tank, through the use of a specially developed organic compound and the addition of extra inputs, without interruption of production (D’Andrea, 2010).

\subsection{Soil Collection}

The soil was collected in sugarcane plantation area, with a history of application of ametryn herbicide, in the region of Piracicaba, in state of the São Paulo, in Brazil, at $20 \mathrm{~cm}$ depth, using a spade and shovel. The soil granulometry used in the experiments was $42 \%$ sand, $33 \%$ clay and $25 \%$ silt, classified as clay-silty sand.

\subsection{Soluble Fraction of Soil in Water}

Weighed was $25 \mathrm{~g}$ of soil into $250 \mathrm{~mL}$ flask and $100 \mathrm{~mL}$ of distilled water were added and the flasks were shaken for $22 \mathrm{~h} \pm 2 \mathrm{~h}$. After this time, the vials were allowed to stand for 30 minutes. The soluble fraction was used in the quantification experiments of bacteria and fungi present in the soil.

\subsection{Estimation of Microbial Activity of The Soil by the FDA Method}

The total soil microbial activity was evaluated by the Fluorescein Diacetate Hydrolysis (FDA) method described by Boehm and Hoitinik (1992). Table 1 shows the experimental design used for the quantification of microbial activity. 
Table 1. Samples performed out in the experiment to estimate microbial activity in soil, with application of ametryn and addition of biofertilizer

\begin{tabular}{|c|c|c|c|}
\hline Samples & $\begin{array}{c}50 \mathrm{~g} \text { of soil } \\
\text { Dry base } \\
\end{array}$ & Ametryn $(\mu \mathrm{g} / \mathrm{L})$ & Biofertilizer (\%) \\
\hline Control soil & + & - & - \\
\hline $\begin{array}{l}8 \mu \mathrm{g} / \mathrm{L} \text { ametryn } \\
+1 \% \text { biofertilizer }\end{array}$ & + & 8 & 1 \\
\hline $\begin{array}{l}8 \mu \mathrm{g} / \mathrm{L} \text { ametryn } \\
+5 \% \text { biofertilizer }\end{array}$ & + & 8 & 5 \\
\hline $\begin{array}{c}8 \mu \mathrm{g} / \mathrm{L} \text { ametryn } \\
+10 \% \text { biofertilizer }\end{array}$ & + & 8 & 10 \\
\hline $\begin{array}{l}12 \mu \mathrm{g} / \mathrm{L} \text { ametryn } \\
+1 \% \text { biofertilizer }\end{array}$ & + & 12 & 1 \\
\hline $\begin{array}{l}12 \mu \mathrm{g} / \mathrm{L} \text { ametryn } \\
+5 \% \text { biofertilizer }\end{array}$ & + & 12 & 5 \\
\hline $\begin{array}{c}12 \mu \mathrm{g} / \mathrm{L} \text { ametryn } \\
+10 \% \text { biofertilizer }\end{array}$ & + & 12 & 10 \\
\hline 8ug/L ametryn & + & 8 & - \\
\hline $12 \mathrm{ug} / \mathrm{L}$ ametryn & + & 12 & - \\
\hline $1 \%$ biofertilizer & + & - & 1 \\
\hline $5 \%$ biofertilizer & + & - & 5 \\
\hline $10 \%$ biofertilizer & + & & 10 \\
\hline
\end{tabular}

This methodology consists in quantifying the hydrolysis of fluorescein diacetate in the soil. The enzymes responsible for the hydrolysis of the FDA are abundant in the soil environment. Non-specific enzymes such as esterases, proteases and lipases have been shown to hydrolyze the FDA, being involved in the decomposition of many types of compounds. The hydrolysis ability of the FDA, appears to be widespread, especially among major decomposers, bacteria and fungi (Schnürer and Rosswall, 1982).

The concentration of FDA hydrolyzate ( $\mu \mathrm{g}$ of FDA hydrolyzed per g-1 of dry soil per minute) was determined with the aid of the standard curve by correlation with the absorbance read in the sample and the FDA hydrolyzed. The calibration curve was obtained by adding FDA at concentrations of $0,20,40,60$ and $80 \mu \mathrm{g} / \mathrm{g}$ dry soil $(0,50,100,150,200 \mu \mathrm{L})$ in $5 \mathrm{~mL}$ of potassium phosphate buffer, contained in test tube. The tubes were sealed and placed in a $100^{\circ} \mathrm{C}$ water bath for one hour for total FDA hydrolysis. After hydrolysis, the FDA was added to a $250 \mathrm{~mL}$ Erlenmeyer flask containing $5 \mathrm{~g}$ of soil and $15 \mathrm{~mL}$ of potassium phosphate buffer. The Erlenmeyer flasks were shaken at $150 \mathrm{rpm}$ at room temperature for 20 minutes. Then, 20 $\mathrm{mL}$ of acetone was added immediately into each vial to stop the reaction. The samples were then centrifuged at $2500 \mathrm{rpm}$ for $15 \mathrm{~min}$ to determine the absorbance in a spectrophotometer at $490 \mathrm{~nm}$.

For the analysis of the samples, $5 \mathrm{~g}$ of each soil sample were placed in duplicate in a $250 \mathrm{~mL}$ 


\section{Macrothink}

Erlenmeyer flask, together with $20 \mathrm{~mL}$ of $60 \mathrm{mM}$ potassium phosphate buffer $\left(8.7 \mathrm{~g} \mathrm{~K}_{2} \mathrm{HPO}_{4}\right.$, $1.3 \mathrm{~g} \mathrm{KH}_{2} \mathrm{PO}_{4}, 1000 \mathrm{~mL}$ water distilled; $\mathrm{pH}$ 7.6). The FDA hydrolysis reaction was initiated with the addition of $0.2 \mathrm{~mL}$ of the FDA stock solution $(2 \mathrm{mg} / \mathrm{mL}$ acetone). The samples were shaken at $150 \mathrm{rpm}$ and incubated at room temperature for 20 minutes.

The reaction was quenched by the addition of $20 \mathrm{~mL}$ of acetone P.A. per vessel, which remained capped until centrifuged. The samples were then centrifuged at $2500 \mathrm{rpm}$ for 15 min. Afterwards, in a spectrophotometer, the absorbance of the centrifuges at $490 \mathrm{~nm}$ was determined.

\subsection{Quantification of the Soil Microbiota}

The soil microbial quantification was expressed in Colony Forming Units per gram of soil (CFU/g soil) of fungi and bacteria, using the Pour Plate method, using Plate Count Agar (PCA), and for fungi the Sabouraud medium, in duplicate.

The soluble fraction of the soil was diluted to the dilution 10-6, withdrawing the $1 \mathrm{~mL}$ aliquot. Dilutions $10^{4}, 10^{5}$ and $10^{6}$ were plated in Petri dishes in the $1 \mathrm{ml}$ aliquot, and then the culture media were added. The plates were incubated for 48 hours at $35.5^{\circ} \mathrm{C}$ for the heterotrophic bacteria, and for fungi were incubated for 72 hours at $28^{\circ} \mathrm{C}$. After the incubation period, the colony forming units were read per gram of soil (CFU/g soil).

\subsection{Analises Estatisticas}

Statistical analyzes of the results were performed using Tykey test, considering a significant difference $p \leq 0.05$, in order to evaluate the different types of treatments, since the data are not distributed normal. The Analyzes Were Performed In Origin 9.0 Software.

\section{Results And discussion}

The table 2, expresses the result of the quantification of heterotrophic bacteria and fungi, and estimate of the enzymatic activity by the FDA method of soil contaminated by ametryn. 


\section{Macrothink}

Table 2. Results of quantification of heterotrophic bacteria and fungi, and estimation of microbial activity by the FDA method

\begin{tabular}{|c|c|c|c|}
\hline Samples & $\begin{array}{c}\text { Heterotrophic } \\
\text { bacteria }\left(\mathbf{1 0}^{6}\right) \\
\text { CFU / g soil }\end{array}$ & $\begin{array}{l}\text { Fungi }\left(10^{6}\right) \\
\text { CFU / g soil }\end{array}$ & $\begin{array}{c}\mu \mathrm{g} \text { FDA } \\
\text { hydrolyzed/g dry } \\
\text { soil }\end{array}$ \\
\hline Control soil & $1.55^{\mathrm{a}}$ & $2.0^{\mathrm{a}}$ & $26.20^{\mathrm{a}}$ \\
\hline $\begin{array}{c}8 \mu \mathrm{g} / \mathrm{L} \text { ametryn }+1 \% \\
\text { biofertilizer }\end{array}$ & $0.8^{\mathrm{b}}$ & $1.8^{\mathrm{a}}$ & $13.73^{\mathrm{b}}$ \\
\hline $\begin{array}{c}8 \mu \mathrm{g} / \mathrm{L} \text { ametryn }+5 \% \\
\text { biofertilizer }\end{array}$ & $1.2^{\mathrm{b}}$ & $1.2^{\mathrm{b}}$ & $24.78^{\mathrm{a}}$ \\
\hline $\begin{array}{l}8 \mu \mathrm{g} / \mathrm{L} \text { ametryn }+10 \% \\
\text { biofertilizer }\end{array}$ & $3.0^{\mathrm{c}}$ & $2.0^{\mathrm{a}}$ & $26.85^{\mathrm{a}}$ \\
\hline $\begin{array}{c}12 \mu \mathrm{g} / \mathrm{L} \text { ametryn }+1 \% \\
\text { biofertilizer }\end{array}$ & $0.1^{\mathrm{d}}$ & $0.20^{\mathrm{c}}$ & $13.78^{b}$ \\
\hline $\begin{array}{c}12 \mu \mathrm{g} / \mathrm{L} \text { ametryn }+5 \% \\
\text { biofertilizer }\end{array}$ & $0.03^{\mathrm{e}}$ & $0.70^{\mathrm{d}}$ & $18.43^{\mathrm{c}}$ \\
\hline $\begin{array}{c}12 \mu \mathrm{g} / \mathrm{L} \text { ametryn }+10 \% \\
\text { biofertilizer }\end{array}$ & $17.0^{\mathrm{f}}$ & $8.9^{\mathrm{e}}$ & $18.72^{\mathrm{c}}$ \\
\hline 8ug/L ametryn & $0.6^{\mathrm{d}}$ & $0.22^{\mathrm{d}}$ & $32.1^{\mathrm{d}}$ \\
\hline $12 \mathrm{ug} / \mathrm{L}$ ametryn & $0.06^{\mathrm{e}}$ & $0.80^{\mathrm{d}}$ & $30.75^{\mathrm{d}}$ \\
\hline $1 \%$ biofertilizer & $0.105^{\mathrm{d}}$ & $0.035^{\mathrm{f}}$ & $22.48^{\mathrm{a}}$ \\
\hline $5 \%$ biofertilizer & $0.045^{\mathrm{e}}$ & $0.255^{\mathrm{d}}$ & $47.93^{\mathrm{e}}$ \\
\hline $10 \%$ biofertilizer & $3.0^{\mathrm{c}}$ & $0.015^{\mathrm{f}}$ & $51.45^{\mathrm{f}}$ \\
\hline
\end{tabular}

Means followed by the same letters do not differ from each other, by the Tykey test at $5 \%$ probability.

The addition of biofertilizer contributed to increase the quantification of heterotrophic bacteria and fungi in soil contaminated by ametryn. The application of carbon source helps in increasing the microbial activity, favoring the metabolization of organic compounds.

Probably, the carbon source from the biofertilizer, with easy access to the microorganisms, helped in its strengthening and enrichment, being verified by the increase of the estimate of the microbial activity by FDA, benefiting in the metabolism of the ametryn, since its biodegradation occurs by cometbolism .

The soil used in the experiments had sandy characteristics, with lower organic matter content. It is known that ametryn has a greater tendency to leach in most soils, but this factor can be maximized in sandy soils (Silva et al., 2012).

Also, the presence of triazine herbicides was observed by Armas et al. (2007) found that ametryn was at higher levels compared to atrazine and simazine. The ametryn presents greater solubility in water and less tendency of adsorption the particles of the ground. In Western Germany, in more than 100.000 samples collected from surface and groundwater, 
$80.7 \%$ of the contaminants were triazine (Beitz et al., 1994).

In this way, the addition of biofertilizer was essential for the increase of microbial activity in soil, as well as in the dissipation of ametryn, reducing its time of permanence in the environment.

\section{Conclusions}

In relation the methods used in the experiments, the microbial quantification by the plating method was simple and fast to obtain the results. However, it can quantify only a small portion of the microorganisms. The enzymatic quantification is more efficient because it quantifies a larger portion of the active microbiota in soil activities.

It is recommended the application of $10 \%$ of biofertilizer, for each $50 \mathrm{~g}$ of soil used with ametryn, in order to result in a greater increase of microbial activity. Also, it is suggested in future works to carry out chromatographic tests in order to confirm the biodegradation of the ametryn molecule, in order to contribute to the understanding of the dissipation of the herbicide in the environment.

\section{References}

Armas, E. D., Monteiro, R. T. R., Antunes P. M., Santos, M. A. P. F., Camargo, P. B., \& Abakerli, R. B. (2007). Spatial-temporal diagnosis of the occurrence of herbicides in surface waters and sediments of the Corumbataí River and main tributaries. New Chemistry, 30, 1119-1127.

Beitz, H., Schmidt, H., \& Herzel, F. (1994). Pesticides in ground and surface water; Börner, H., ed.; Springer-Verlag: Berlin

Bettiol, W., Tratch, R. \& Galvao, J. A. H. (1998). Control of plant diseases with biofertilizers. EMBRAPA - CNPMA, 1, 1-22.

Boehm, M. J., \& Hoitink, H. A. J. (1992). Sustenance of microbial activity in potting mixes and its impaction severity of Pythium root of Poinsettia. Phytopathology, 82, 259-264. https://doi.org/10.1094/Phyto-82-259

D'Andrea, P. A. (2002). Continuous liquid composting process - CLC and Biofertilizer. Microbiol Industry and Trade LTDA. (BR/SP). N 2099 Registro PI0207342-0 A2.

Jilani, G., Akram, A., Ali, R. M., Hafeez, F. Y., Shamsi, I. H., .. \& Chaudhry, A. G.. (2007). Enhancing crop growth, nutrients availability, economics and beneficial rhizosphere microflora through organic and biofertilizers. Annals of Microbiology, 57, 177-183. https://doi.org/10.1007/BF03175204

PPDB. Pesticides properties database - Ametryn. University of Hertfordshire, 2018.

Régo, A. P. J., Reganhan-Coneglian, C. M., Montagnolli, R. N., \& Bidoia, E. D. (2014). $\mathrm{CO}_{2}$ production of soil microbiota in the presence of ametryne and biofertilizer. Water Air Soil Pollution, 225, 1-6. https://doi.org/10.1007/s11270-014-2222-4 
Santos, A. C. V. Biofertilizer liquid, the nature's defense. (1992). Niterói: EMATER. Agropecuária Fluminense, 16.

Schnurer, J., \& Rosswall, T. (1982). Fluorescein diacetate hydrolysis as a measure of total microbial activity in soil an litter. Applied Environmental Microbiology, 43, 1256-1261.

Silva, L. O. C., Silva, A. A., D’Antonino, L., Queiroz, M. E. L. R., Lima, C. F., \& Freitas, F. C. L. (2012). Sorption and desorption of ametryn in Brazilian Oxisols. Planta Daninha, 30, 633-640. https://doi.org/10.1590/S0100-83582012000300020

Souza, J. L., \& Resende, P. (2003). Manual of organic horticulture. Viçosa: Learn Easy., 564.

\section{Copyright Disclaimer}

Copyright for this article is retained by the author(s), with first publication rights granted to the journal.

This is an open-access article distributed under the terms and conditions of the Creative Commons Attribution license (http://creativecommons.org/licenses/by/4.0/). 